\title{
Lower Limb Injuries and Socioeconomic Influences in a Region of a Tertiary Hospital in São Paulo, Brazil
}

\author{
${ }^{1}$ Taís Martins Loreto, ${ }^{2}$ Marcus Vinicius Boaretto Cezillo, ${ }^{3}$ Bruno Rafael Müller, ${ }^{4}$ Rodrigo Chaves Ribeiro \\ ${ }^{5}$ Ana Aparecida Andrade, ${ }^{6}$ Simone de Campos Vieira Abib
}

\begin{abstract}
Background: Lower limb injuries are related to important disability to deal with environment. Socioeconomic characteristics also must be considered since they lead to a particular trauma profile. This association is necessary to guide control measures to prevent morbidity and mortality.
\end{abstract}

Study design: In the region, the human development index (HDI) varies from 0.772 to 0.804 ), per capita income varies from 1.62 to 2.36 (minimum wage) and the average years of study in the population was 6.5 years. Data collected from 334 admitted trauma patients between 2011 and 2012 at Hospital Pirajussara, a tertiary reference center in São Paulo, Brazil, linked to the Federal University of São Paulo, Paulista School of Medicine (UNIFESP-EPM) compiled the following parameters: length of stay, age, sex, mechanism of injury and mortality, which was associated with the local characteristics and data from the existing literature. The environment characteristics surrounding the hospital are of slums without adequate work conditions.

Results: Domestic falls were the most important mechanism of injury (50.8\%), affecting mainly elderly people at the rate of $33.5 \%$ with femur fractures. Traffic accidents involved $27.2 \%$ of patients, $71.4 \%$ of them caused by motorcycle. Seventy-seven percent of motorcycle accidents involved young drivers with lower leg injury (69.2\%) and hip/thigh injury (26\%).

Conclusion: Results demonstrate that most lesions are motivated by domestic falls and are strongly correlated to elderly patients, while young patients are more inclined to suffer traffic accidents, mostly associated with motorcycles. Considering this peculiar epidemiological profile is possible to intervene through policy approaches, such as safer road infrastructure and enforcement of laws to decrease risky behavior, and third age public healthcare strategies allied to better structured homes, using assistive devices as handrails for stairways and removing hazards from passage.

\footnotetext{
${ }^{1-3}$ Medical Student, ${ }^{4,6}$ Professor, ${ }^{5}$ Coordinator

${ }^{1-4,6}$ Department of Surgery, Federal University of São Paulo Paulista School of Medicine (UNIFESP-EPM), São Paulo, Brazil

${ }^{5}$ Department of Epidemiological Surveillance, Federal University of São Paulo, Paulista School of Medicine (UNIFESP-EPM), São Paulo, Brazil

Corresponding Author: Taís Martins Loreto, Academic Department of Surgery, Federal University of São Paulo Paulista School of Medicine (UNIFESP-EPM), São Paulo Brazil, Phone: 5511952960104, e-mail: taismlo@hotmail.com
}

Keywords: Accidents, Epidemiology, Injuries, Lower limb, Panamerican trauma society, Public health, Socioeconomic, Trauma.

How to cite this article: Loreto TM, Cezillo MVB, Müller BR, Ribeiro RC, Andrade AA, Abib SCV. Lower Limb Injuries and Socioeconomic Influences in a Region of a Tertiary Hospital in São Paulo, Brazil. Panam J Trauma Crit Care Emerg Surg 2014;3(2):47-52.

\section{Source of support: Nil}

Conflict of interest: None

\section{ABSTRACTO}

Antecedentes: Lesiones de las extremidades inferiores están relacionadas con importantes discapacidades a interactuar con el medio ambiente. Las características socioeconómicas también deben ser consideradas ya que conducen a un particular perfil de trauma. Esta asociación es necesaria para guiar medidas de control para prevenir la morbilidad y la mortalidad.

Diseño del estudio: En la región, el índice de desarrollo humano (IDH) varía de 0,772 a 0,804, el ingreso per cápita varía de 1,62 a 2,36 (salario mínimo) y el promedio de años de estudio en la población fue de 6,5 años. Los datos recogidos de los 334 pacientes admitidos de trauma entre 2011 y 2012 en el Hospital Pirajussara, un centro de referencia terciario en São Paulo, Brasil, vinculado a la Universidad Federal de São Paulo, la Escuela Paulista de Medicina (Unifesp-EPM) compiló los siguientes parámetros: longitud de alojarse, edad, sexo, mecanismo de la lesión y mortalidad, que era asociado con las características locales y los datos de la literatura existente. Las características del ambiente de los alrededores del hospital son de barrios pobres sin condiciones de trabajo adecuadas.

Resultados: El mecanismo más importante de lesiones fue las caídas domésticas $(50,8 \%)$, que afectan a las personas de edad avanzada, principalmente, a la tasa de $33,5 \%$ con fracturas de fémur. Los accidentes de tráfico involucran $27,2 \%$ de pacientes, donde $71,4 \%$ de ellos son causados por motocicletas. Setenta y siete por ciento de los accidentes de motocicleta con conductores jóvenes ocurre lesión inferior de la pierna $(69,2 \%)$ y lesión de cadera / muslo $(26 \%)$.

Conclusión: Los resultados demuestran que la mayoría de las lesiones son motivadas por las caídas domésticas y están fuertemente correlacionadas con pacientes de edad avanzada, mientras que los jóvenes son más proclives a sufrir accidentes de tránsito, en su mayoría asociados a las motocicletas. Teniendo en cuenta este perfil epidemiológico peculiar es posible intervenir a través de enfoques de política, como carreteras más seguras y aplicación de leyes para disminuir 
el comportamiento riesgoso, y políticas públicas para la tercera edad aliadas a hogares mejor estructurados, utilizando dispositivos de asistencia como pasamanos por las escaleras y la eliminación de los peligros de pasaje.

Palabras clave: Accidentes, Epidemiología, Lesiones, Miembro inferior, Sociedad Panamericana de Trauma, Salud pública, Socioeconómico, Trauma.

\section{INTRODUCTION}

Deaths from external causes are the third issue in Brazil, a fact that prevents an increase in life expectancy of Brazilians. ${ }^{1}$ Younger people hold comparable statistics to major armed conflicts in the world. ${ }^{2}$ Not only violence but transport accidents and home accidents victimize people for all ages, resulting in disability, scholar/work absence and rising of the costs to the health system.

In particular, lower limb injuries are related to important disability to deal with the environment and have significant impact on functional long-term recovery. Numerous investigations identified further noninjury-related factors influencing outcome, quality of life and life satisfaction, such as education and income are significant sociodemographic parameters associated with long-term outcome. ${ }^{3}$ Not only outcome but also the traumatic injury are problems often determined by behavioral, demographic and vocational factors are commonly known as sustaining risk factors, but less is known about the social, demographic and economic determinants of outcome following injury. ${ }^{4}$

The study lower extremity assessment project conducted by Cannada and Jones, 2006 evaluated 601 patients in a cohort at 7 years postinjury. Results showed that factors other than the traditional variables such as fracture healing, joint function and ability to ambulate have a profound effect on the patient's estimation of improvement and data like demographic, social and behavioral factors impact on the incidence and outcome following lower extremity injury. ${ }^{5}$

This reality requires research to substantiate the particularity of risk groups in the form of social differences. Furthermore, the risk factors for the occurrence of injuries due to external causes, such as poor socioeconomic status, the association and effects of such injuries within social relations are not known in São Paulo. ${ }^{6}$

This scenario shows the need for an association between the epidemiological profile of the mechanisms of trauma and the socioeconomic characteristics in order to control measures, allowing the interruption of the transmission chain of violence and preventing accidents among the population. In this context, the partnership between referral hospitals and epidemiological surveillance system in field hospital provides support for enhancing surveillance and is an important tool for the planning of hospital management and public policy. ${ }^{7}$ Thus, it is intended thereby to improve hospital routines and increases the efficiency of emergency care/trauma emergency patients.

\section{METHODS OF RESEARCH}

\section{Study Design and Setting}

This is a retrospective, observational, single center study which analyzes data about the nonfatal trauma suffered by victims of trauma requiring hospitalization in a tertiary hospital in the outskirts of São Paulo, during the period from January 2011 to June 2012.

\section{Ethical Aspects}

This study was approved by the Ethics Committee of Federal University of São Paulo, Paulista School of Medicine (No. 110.123).

\section{Study Site}

The study was based on data obtained from the Pirajussara General Hospital (PGH). Opened in 1999, PGH is the benchmark for health to about 500,000 people in the region of Embu das Artes and Taboão da Serra in São Paulo state and is a center of high complexity for 2.7 million people from 15 nearby cities.

\section{Socioeconomic Status Data}

The socioeconomic status data was collected from the existing literature from SEADE, 2012 (Table 1), a Brazilian unified health system database and other health database. The socioeconomic indicators of the two main cities served by the hospital (Taboão da Serra and Embu das Artes) were acquired from the database and an average of the indicator was used to draw a socioeconomic profile of the region. ${ }^{8}$

\section{Patient Data Collection}

The epidemiologic surveillance center of the PGH has a team responsible for documenting data of patients attended in the hospital. All admissions of trauma patients are filed. The data are transferred to the software Microsoft Excel ${ }^{\mathbb{R}}$.

All trauma patients admitted to this service had a protocol completed by nursing staff that make up the epidemiologic surveillance center of the PGH with the following parameters: date of admission, hospital record number, sex, age, mechanism of injury, International Classification of Disease, date of hospital discharge and mortality.

\section{Patient Selection}

The study included admitted patients who were victims of lower limb injuries and were treated by in the PGH during the period from January 2011 to June 2012. 
Table 1: Social indicators of the two main cities that refers patients to the PGH, acquired from SEADE, 2012

\begin{tabular}{lll}
\hline Social indicators $^{8}$ (2012) & Embu das Artes & Taboão da Serra \\
\hline Human development index & 0.772 & 0.894 \\
Per capita income (minimum wage) & 1.62 & 2.36 \\
Urban homes with inner adequate infrastructure (\%) & 68.8 & 88.3 \\
Homes with enough space (\%) & 70.0 & 74.5 \\
Population 60 years and over & 7.58 & 8.63 \\
Average years of study in the population (15-64 years) & 6.5 & 7.2 \\
\hline
\end{tabular}

\section{Statistical Analysis}

Frequencies and proportions were examined for all variables. All analyzes were performed using the software Microsoft Excel $^{\mathbb{R}}$.

\section{RESULTS}

During the period of observation from January 2011 to June 2012, 334 lower limb trauma patients have been admitted at PGH. Of these, $236(70.7 \%)$ were males and $98(29.3 \%)$ were females.

Socioeconomic indicators of PGH surroundings, including the human development index (HDI), per capita income and average years of study of the population were collected and analyzed in order to characterize the patients social status (see Table 1).

In the region, the HDI varies from 0.772 to 0.804 , per capita income varies from 1.62 to 2.36 (minimum wage) and the average years of study in the population was 6.5 years.

Concerning the mechanism and type of injury, two major causes were observed: domestic falls and traffic accidents (Graph 1).

Other multiple remaining causes were listed, such as physical aggression, work accidents involving falls from scaffolds or elevations, industrial machinery operation and sport accidents related specially to football. Nevertheless, these later causes were associated with very low rates of occurrence in the present series.

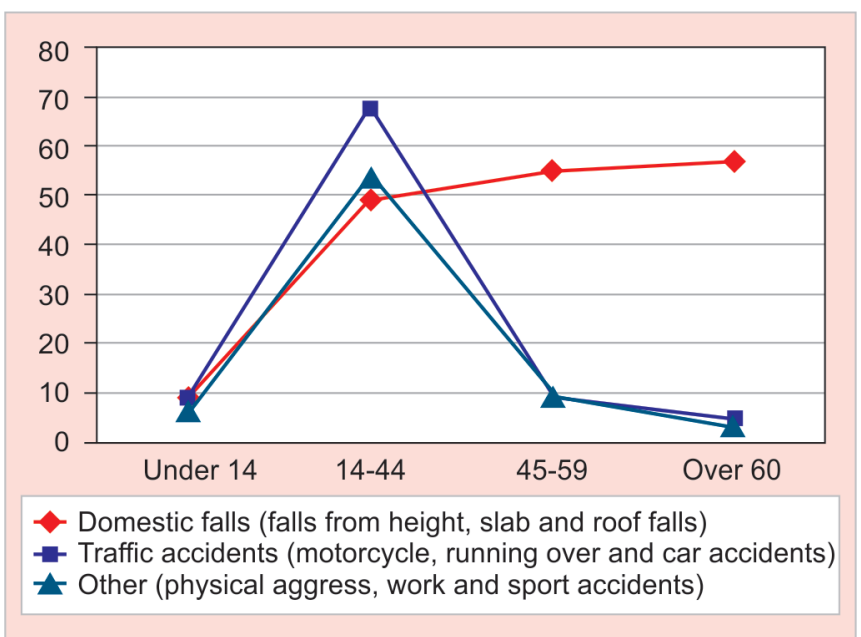

Graph 1: Distribution of lower limb injuries by cause and age group

\section{Domestic Falls}

The most significant mechanism of injury was motivated by domestic falls $(50.8 \%)$. The average age of hospitalized patients was 51.3 years old (1-98 years) and formed largely by males $(55.9 \%)$. The average length of stay was 7.2 days (1-68 days). Elderly people (60-98 years old) were the mainly affected at the rate of $33.5 \%$, with femur fracture.

In relation to the 170 considered domestic falls, 97 (57\%) of them were falls from height, whereas $49(28.8 \%)$ corresponded to stairs falls and $5(2.9 \%)$ to slab falls. Not more than four cases were motivated by roof falls, the equivalent to $2.3 \%$ of the total (Fig. 1). Unlike most of domestic falls (falls from height and stairs falls), roof and slab falls were exclusively correlated to young patients (2-17 years old).

Ankle lesions were registered at the number of 62 cases, the correspondent to $36.4 \%$, while foot trauma had the occurrence rate of $11.7 \%$ of home accidents. Other categories of injury such as leg, hip and thigh lesions had a minor participation in this context.

\section{Traffic Accidents}

The second pattern of trauma of lower limb was characterized by traffic accidents (27.2\%). The average age of patients was 36 years old (4-78 years) and the male:female rate was 6:1. The average length of stay was 6.8 days (0-18 days).

Motorcycle accidents were responsible for $71.4 \%$ of traffic accidents, representing 65 cases in a total of 91 admis-

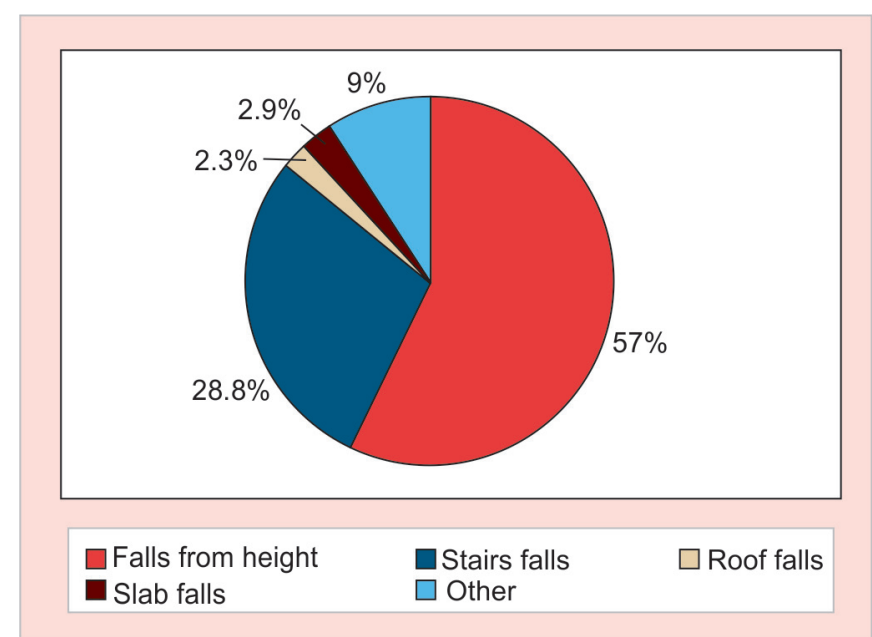

Fig. 1: Distribution of causes of domestic falls 
sions. Young drivers ( $16-35$ years) were involved in $77 \%$ of motorcycle accidents. Within this context, $69.2 \%$ of juvenile patients were hospitalized with lower leg injury and $26 \%$ of them had associated hip/thigh injury.

Running over represented $24.2 \%$ of traffic accidents, being that age distribution in this group tended to be regularly wide-ranging, from 4 to 78 years old, affecting mainly men at the rate of $68.1 \%$. From a total of 22 cases of running over, 8 (36.4\%) affected 0-14 years old population. People aged between 14 and 44 years old were involved in four cases $(18.2 \%)$, whilst five cases (22.7\%) occurred with individuals between 44 and 59 years old. At least five cases (22.7\%) involved elderly patients. Half of running over trauma involved ankle/foot injuries. Car accidents (4.4\%) were found in this context of trauma related to traffic accidents though associated with a reduced incidence.

\section{Mortality}

Among the lower limb trauma patients, the death rate was $2.4 \%$. The average length of stay was 13.1 days. Femur fracture was the main type of injury at the rate of $62.5 \%$ deaths. The average age of patients who died was 59 years, formed principally by men (75\%). Domestic falls were responsible for $87.5 \%$ of deaths, while motorcycle were accountable for the rest.

\section{DISCUSSION}

Traumatic events have a considerable impact on the Brazilian health system, causing significant financial burden to society and to affected individuals, as well as prevent an increase in life expectancy, ${ }^{9}$ which should not be ignored.

Patients affected with lower limb injuries usually have poor functional outcomes, ${ }^{10,11}$ and nearly a quarter of injured individuals with lower limb fracture stay away from work for a period of 1 year or more, ${ }^{12}$ as reported by previous studies. Severe lower extremity injuries can lead to a significant number of complications, a large portion of patients will require additional inpatient or operative treatment. ${ }^{13}$

Therefore, in order to direct measures to prevent trauma injuries and to improve the health public care, it is necessary to determine the epidemiological and socioeconomic profile of the patients. The understanding of the impact and consequences of trauma in the society should encompass the entire spectrum of accidents, facilitating the identification of priorities of prevention and public laws. ${ }^{14,15}$

Individual education level and occupation were associated with all-cause mortality, according to a recent Japanese study (2013). Municipal and individual socioeconomic conditions were independently and interactively associated with premature death, this suggests that reducing social inequalities in health demands a focus on municipal conditions in addition to those of individuals. Primary predictors were municipal socioeconomic conditions (proportion of college graduates, per capita income, unemployment rate and proportion of households receiving public assistance) and individual socioeconomic conditions (education level and occupation). ${ }^{16}$ In the PGH region, the HDI varies from 0.772 to $0.804,{ }^{8}$ while Norway leads the world ranking of HDI (0.955), ${ }^{17}$ highlighting that external causes correspond to only $5.8 \%(2012)^{18}$ of all causes of death in that country, contrasting with $12.4 \%(2011)^{1}$ in Brazil. Per capita income varies from 1.62 to $2.36,{ }^{8}$ which corresponds to the minimum wage. The average years of study in the population was 6.5 years, ${ }^{8}$ approximately 5.5 years below the rates of developed countries. ${ }^{19}$

The purpose of epidemiological surveillance in the hospital is to detect and investigate reportable diseases treated in the hospital. The Brazilian government introduced a national epidemiological surveillance subsystem in the creation of a network of 190 hospital epidemiology nuclei in reference hospitals in Brazil. The purpose of the subsystem creation is to improve the surveillance by expanding its network of reporting and investigation of injuries. ${ }^{7}$

The State of São Paulo has 39 cores in hospitals spread across health regions, one of them being the HGP. The professionals of health centers detect diseases of compulsory notification from active search in strategic locations in the hospital, such as emergency rooms, laboratory and infirmary injuries. ${ }^{7}$ Unfortunately, trauma is not compulsory notified in Brazil yet, which shows the significance of the hospital surveillance system.

The death rate was $2.4 \%$ among lower limb injuries, domestic falls being responsible for $87.5 \%$ of deaths. Those data differ from the hospital mortality rate for all falls was $5.3 \%$ in a study made by the epidemiologic surveillance center - State Secretariat of Health of São Paulo state (2007-2008), which can be explained by a larger variety of complexity and severity of injuries, resulting in higher taxes of mortality. ${ }^{20}$

In Brazil, $79 \%$ of mortality in individuals aged between 0 and 14 years old is due to external causes. Traffic accidents are responsible for half of mortality in this age group, especially running over accidents. ${ }^{1}$ In this study, $36.4 \%$ of accidents related to running over affected 0 to 14 years old population. As for elderly patients, this rate drops down to $22.7 \%$ in comparison to $15.7 \%$ of running over accidents participation in traffic accidents in Brazil. ${ }^{1}$

The male predominance found in this trauma study (70.7\%) is consistent with the data literature of larger number of men in public healthcare related to external causes both in Brazil and in other countries. ${ }^{21-24}$ This fact can be explained 
by the higher risky behavior among men, ${ }^{25}$ especially when considering high energy trauma, such as traffic accidents, responsible for $27.2 \%$ of lower limb injuries in this study.

Motorcycle accidents were responsible for $71.4 \%$ of traffic accidents involving significantly young drivers. Metropolitan areas deal with the increased number of motorcycles, as a means of locomotion and work, however, many drivers dispense prudent attitudes, as exceed speed limits and use of illicit substances. The number of deaths from this type of accident increased by $21 \%$ in recent years-from 8,898 motorcyclists in 2008 to 10,825 deaths in 2010 in Brazil. ${ }^{1}$ It is possible to intervene through policy approaches, such as safer road infrastructure to eliminate the signaling failures and irregularities in asphalt. In addition, the enforcement of laws to decrease risky behavior, such as fiscalization on alcohol and drugs use and vehicle safety check ups.

Domestic falls motivated $50.8 \%$ of lower limb injuries in PGH and were strongly correlated to elderly patients $(33.5 \%)$. Of these, $57 \%$ corresponded to falls from height, coincident data in many preceding studies, ${ }^{25,26}$ whereas $28.8 \%$ corresponded to stairs falls. In Europe, falls are estimated at $53 \%$ of all home accidents, which indicates the importance of this mechanism of injury worldwide. ${ }^{27}$

Unlike most domestic falls (falls from height and stairs falls), roof and slab falls were exclusively correlated to young patients (2-17 years old). A recent Brazilian study states that the predominant age group in this pattern of trauma was school children and leisure activities were most frequently being practiced on the roof slab at the time of the fall $(86 \%)$. In $72 \%$ of the cases, the children were unaccompanied by an adult responsible for them, which calls attention to prevention measures as informing parents and physical protective measures as gates with lockers to restrict free access to these areas. ${ }^{28}$

The aging process implies changes in reflexes and balance control, jeopardizing the body mobility as well as reduced speed and strength. In a recent systematic review, it was concluded that interventions to prevent falls in the elderly have been effective, with $10 \%$ reduction in rates of fall. ${ }^{22}$ Educational strategies such as better structured homes for elderly should be promoted, stressing the importance of using assistive devices as handrails for stairways and removing hazards from passage as well as appropriate training for home caregivers and home visitors. ${ }^{29}$

It is important to take into consideration the possible limitations of this study, such as the absence of information from the patient evolution and recovery and complications during hospitalization. In addition, there were limitations in data collection, which allows the occurrence of information bias, lack of data and inaccurate measurements. The socioeconomic parameters used in the study were not collected individually, but were based on the official epidemiologic profile information of the cities of Taboão da Serra and Embu das Artes. Nevertheless, this study can contribute to understand the present factors associated with lower limb injuries and outline adequate prevention methods.

\section{CONCLUSION}

This study demonstrates the vulnerability to dangers that domestic and public background presents to the population. Moreover, it conjectures that the pattern of trauma seen in a tertiary hospital in the periphery of São Paulo city is influenced by regional socioeconomic characteristics. Strengthening interface between hospital and community, based on the observation and surveillance is fundamental to promote health and prevent accidents.

\section{REFERENCES}

1. DATASUS. Department of the data processing of the unified healthy system, executive secretary of the ministry of health mortality information system - MIS. Deaths by occurrence second Chapter ICD-10 (2011). Available at: www.datasus.gov. br (Accessed 12 Nov, 2013).

2. Waiselfisz JJ. Map of Violence 2012: New patterns of homicidal violence in Brazil. 1st ed. 2012.

3. Pfeifer R, Lichte P, Zelle BA, Sittaro NA, Zilkens A, Kaneshige JR, Pape HC. Socioeconomic outcome after blunt orthopaedic trauma: Implications on injury prevention. Patient Saf Surg 2011;5(9):1-6.

4. MacKenzie EJ, Bosse MJ. Factors influencing outcome following limb-threatening lower limb trauma: lessons learned from the lower extremity assessment project (LEAP). J Am Acad Orthop Surg 2006;14(10 Spec No.):S205-S210.

5. Cannada LK, Jones AL. Demographic, social and economic variables that affect lower extremity injury outcomes. Injury 2006;37(12):1109-1116.

6. Cubbin C, LeClere FB, Smith GS. Socioeconomic status and the occurrence of fatal and nonfatal injury in the United States. Am J Public Health 2000;90(1):70-77.

7. Health Secretary of State of São Paulo - Subsystem Surveillance Scope Hospital in the State of São Paulo. Epidemiological surveillance at hospital level. Rev Saude Publica 2007;41(3):487-491.

8. State System of Data Analysis (SEADE) - Brazilian unified health system database State System of Data Analysis (SEADE). Social Indicator Information. Profile of the Brazilian cities. Brazil, 2012.

9. Brazilian Institute of Geography and Statistics - IBGE. Available at: http://www.ibge.gov.br/home/estatistica/populacao/ tabuadevida/evolucao_da_mortalidade_2001.shtm (Accessed 9 Nov, 2013).

10. Balogh ZJ, Reumann MK, Gruen RL, Mayer-Kuckuk P, Schuetz MA, et al. Advances and future directions for management of trauma patients with musculoskeletal injuries. Lancet 2012;380:1109-1119.

11. Zelle BA, Brown SR, Panzica M, Lohse R, Sittaro NA, Krettek C, et al. The impact of injuries below the knee joint on the long-term functional outcome following polytrauma. Injury 2005;36(1):169-177. 
12. Harris AM, Althausen PL, Kellam J, Bosse MJ, Castillo R. Lower extremity assessment project (LEAP) study group. Complications following limb-threatening lower extremity trauma. $\mathrm{J}$ Orthop Trauma 2009;23(1):1-6.

13. MacKenzie EJ, Morris JA Jr, Jurkovich GJ, Yasui Y, Cushing BM, Burgess AR, et al. Return to work following injury: the role of economic, social and job-related factors. Am J Public Health 1998;88(11):1630-1637.

14. Polinder S, Haagsma JA, Toet H, van Beeck EF. Epidemiological burden of minor, major and fatal trauma in a national injury pyramid. Brit J Surg 2012;99 Suppl 1:114-121.

15. Barata RC. The challenge of emergent diseases and the return to descriptive epidemiology. Rev Saude Publica 1997;31(5):531537.

16. Honjo K, Iso H, Fukuda Y, Nishi N, Nakaya T, Fujino Y, et al. JACC Study Group. Influence of municipal- and individual-level socioeconomic conditions on mortality in Japan. Int J Behav Med 2013 Sep 21. [Epub ahead of print].

17. International Human Development Indicators. Norway. Country Profile: Human Development Indicators. Available at: http:// hdrstats.undp.org/en/countries/profiles/NOR.html (Accessed 9 Nov, 2013).

18. Statics Norway. Causes of death, 2012. Available at: http://www. ssb.no/en/dodsarsak/ (Accessed 9 Nov, 2013).

19. OECD - Social Policy Division - Directorate of employment, labour and social affairs. $\mathrm{CO}_{3} .1$ : Educational attainment by gender and average years spent in formal education. Available at: http://www.oecd.org/els/family/CO $.1 \% 20$ Educational $\% 20$ attainment $\% 20$ by $\% 20$ gender $\% 20-\% 20$ updated $\% 20051012$.pdf (Accessed 9 Nov, 2013).
20. Gawryszewski VP. The importance of falls on the same level among the elderly in São Paulo state. Rev Assoc Med Bras 2010; 56(2):162-167.

21. Castro MB, Rendón LF, Rojas MC, Durán CA, Albornoz M. Characterization of patients with lesions of violent traumatic origin by means of an epidemiologic surveillance system. Rev Colomb Cir 2006;21(3):180-189.

22. Centers for Disease Control and Prevention. Welcome to WISQARS. Available at: http://www.cdc.gov/ncipc/wisqars (Accessed 9 Nov, 2013).

23. Gawryszewski VP, Rodrigues EMS. The burden of injury in Brazil, 2003. São Paulo Med J 2006;124(4):208-213.

24. Gawryszewski VP, Scarpelini S, Dib JA, Jorge MHPM, Pereira GA Jr, Morita M. Treatment of injuries in emergency departments: characteristics of victims and place of injury, São Paulo State, Brazil, 2005. Cad Saúde Pública 2008;24(5):1121-1129.

25. Broska Júnior CA, De Folchini AB, Ruediger RR. Comparative study of trauma in the elderly and nonelderly patients in a university hospital of Curitiba. Rev Col Bras Cir 2013;40(4): 281-286.

26. Mascarenhas MDM, Silva MMA, Malta DC, Moura L, Gawryszewski VP, Costa VC, et al. Unintentional injuries at the emergency department injury surveillance system-Brazil, 2006. Cienc Saude Colet 2009;14(5):1657-1668.

27. Angermann A, Bauer R, Nossek G, Zimmermann N. Injuries in the European Union. Statistic Summary 2003-2005. Austria KfV, 2007.

28. Rudelli BA, Silva MV, Akkari M, Santili C. Accidents due to falls from roof slabs. São Paulo Med J 2013;131(3):153-157.

29. Choi M, Hector M. Effectiveness of intervention programs in preventing falls: a systematic review of recent 10 years and meta-analysis. J Am Med Dir Assoc 2012;13(2):188.e13-21. 